Liturgia Sacra 24 (2018), nr 1, s. 255-266

DOI: $10.25167 / \mathrm{LitS} / 24(2018) 1 / 255-266$

ADAM RosińsKI

Wydział Sztuki, UW-M

\title{
Zastosowanie technologii cyfrowych w materialnej przestrzeni budynków sakralnych
}

Kościół od zawsze charakteryzował się dążeniem do tradycji niezależnie od przychylności czasów, w których przyszło żyć ludziom (ataki na chrześcijan od czasów Nerona, rewolucja przemysłowa, zmiany polityczne, klęski żywiołowe, wojny, postępująca cyfryzacja życia ludzkiego). Kościół opierając się wpływom zewnętrznym, nieraz udowadniał, jaką ma siłę, tworzoną przez wspólnotę ludzi pielęgnujących tradycyjne podejście do religii i wiary ludzkiej w Boga, która spajała więzy ludzkości, przez wieki przybliżając człowieka w wierze ku Bogu bez względu na zaistniałe zmiany, które niejednokrotnie celowo były wymierzone w dobre imię Kościoła.

Od kilkunastu lat możemy zaobserwować gwałtowny, niepohamowany oraz ciągły postęp technologiczny, występujący niemal we wszystkich dziedzinach życia ludzkiego ${ }^{1}$, który powoduje głębokie zmiany we współczesnym społeczeństwie $^{2}$. Łatwy dostęp do informacji uzyskiwanych drogą elektroniczną oraz coraz prostsza obsługa urządzeń cyfrowych sprawia, że urządzenia współczesnej techniki są nieodzowne w życiu i kulturze współcześnie żyjących ludzi ${ }^{3}$. Wpływ różnych technologii cyfrowych (w tym informacyjnych) na społeczeństwo, które aktualnie jest silnie związane z mediami, Internetem oraz elektroniką użytkową, powoduje powstawanie nowego modelu społeczeństwa, nazywanego społeczeństwem multi-

${ }^{1}$ E. GAJEK, Edukacja językowa w społeczeństwie informacyjnym, Warszawa 2008, s. 18-19.

2 P. SienKIEwicz, Spoleczeństwo informacyjne jako społeczeństwo ryzyka, w: L.H. HABER, M. NIEzGoda (red.), Społeczeństwo informacyjne. Aspekty funkcjonalne i dysfunkcyjne, Kraków 2006, s. 61.

${ }^{3}$ L. PAWELSKI, Komputer jako narzędzie pracy dydaktycznej $i$ administracyjnej $w$ szkole, w: Z. PŁoszyński, A. Patryn (red.), Komputer - współczesne narzędzie pracy nauczyciela, Słupsk 2003, s. 84-85. 
medialnym ${ }^{4}$. Społeczność ta $\mathrm{w}$ życiu codziennym oraz $\mathrm{w}$ wielu dziedzinach życia ludzkiego korzysta z szeroko pojętej technologii cyfrowej, często nawet nie zdając sobie sprawy z tego, że staje się silnie uzależniona od teraźniejszej i przyszłej cyfryzacji ${ }^{5}$.

Współczesny Kościół stoi przed wyzwaniami wykorzystania technologii cyfrowych w domach modlitwy. Coraz większa dostępność komputerów na rynku, szeroki ich rozwój wraz z różnymi technologiami multimedialnymi prowadzi do wpływu tych zjawisk także na zastosowanie nowoczesnych technologii w Kościele. Szybki rozwój nowoczesnych narzędzi oraz coraz większa ich dostępność powoduje, że cena dzisiejszych komputerów i urządzeń skomputeryzowanych jest coraz niższa, zastępując coraz częściej elementy ważnej tradycji chrześcijan, które w pewnych przypadkach należałoby pozostawić w niezmienionym od lat kształcie.

\section{Cyfrowe modelowanie akustyki obiektów sakralnych}

Zarówno akustyka, jak i architektura pełnią bardzo ważną rolę w projektowaniu i wznoszeniu wszystkich wnętrz sakralnych. Przed wiekami odbiór treści akustycznych był porównywalny z odbiorem treści wizualnych. $\mathrm{Z}$ wielkim znawstwem i starannością projektowano wszelkie elementy w sposób bardzo szczegółowy. Projektowane różnego rodzaju detale, będące we wnętrzu kościoła, miały w sposób bezpośredni lub pośredni oddziaływać na akustykę ${ }^{6}$. Pomimo braku komputerów i urządzeń cyfrowych trafnie przewidywano akustykę danego obiektu sakralnego oraz, czy kościół będzie spełniał stawiane kryteria oceny jakości dźwiękowej - zrozumiałości słowa mówionego oraz śpiewanego wraz z akompaniamentem liturgicznym.

Współcześnie wznoszone świątynie nie brzmią właściwie, co wskazuje, że tak ważny element, jak akustyka obiektów sakralnych, jest w znacznej części pomijana przez architektów. Wynikłe komplikacje, będące następstwem nieprzemyślanego pod względem akustycznym projektu architektonicznego, powodują znaczne problemy w zakresie odbioru treści akustycznych (mówionych), które są podstawą nauczania Kościoła ${ }^{7}$. Coraz mniejsza liczba godzin przedmiotu ,akustyka” na kie-

${ }^{4}$ A. Rosiński, Cyberkultura i twórczość digitalna jako moda $w$ społeczeństwie multimedialnym, „Muzyka. Historia. Teoria. Edukacja” 6 (2016), Bydgoszcz 2016, s. 75.

5 T. Flew, Media globalne, (tłum. M. Lorek), Kraków 2010, s. 161.

${ }^{6}$ A. Kulowski, D. WróblewsKa, Czynniki akustyki w architektonicznym projektowaniu kościołów, Gdańsk 2007, s. 20-23.

${ }^{7}$ B. Szudrowicz, Normowanie wartości czasu pogłosu w pomieszczeniach - założenia do normy PN, „Materiały Budowlane” 8 (2009), s. 9; T. KAMIŃSKI, K. KosAŁA, Akustyka wielofunkcyjna wnętrz 
runkach związanych z projektowaniem i architekturą lub całkowity brak w siatce kierunku takiego przedmiotu powodują, że aktualnie istnieje tendencja do wznoszenia domów modlitwy na planie różnego rodzaju owali ${ }^{8}$. Plan budynku o przeznaczeniu eucharystycznym na bazie kształtów eliptycznych spełnia zawsze wszelkie wymogi wizualne, natomiast bardzo rzadko wymogi akustyczne. Kościół o takim kształcie w większości przypadków charakteryzuje się trudnościami i błędami akustycznymi, stąd cyfrowe modelowanie akustyki obiektów sakralnych, umożliwia częściowe korygowanie błędów technologią komputerową, co współcześnie jest wykorzystywane dość często9.

Niewłaściwy wybór sprzętu elektroakustycznego względem pomieszczenia, w którym ma pracować system elektroakustyczny (wzmacniacz, linia opóźniająca, zespoły głośników oraz mikrofony), powoduje problemy ${ }^{10} \mathrm{~W}$ zakresie:

- czytelności i zrozumiałości słowa mówionego przez kapłana oraz śpiewanego przez organistę;

- kierunku dochodzących dźwięków, na tle innych dźwięków, względem kapłana prowadzącego Mszę (odnosi się wrażenie jakby osoba duchowna stała i mówiła do nas z boku, a nie będąc w prezbiterium np. przy ołtarzu lub mównicy);

- wzbudzania urządzeń elektroakustycznych (zbyt dużo mikrofonów i głośników nieskalibrowanych między sobą), które wpływając na siebie, mogą buczeć i szumieć;

- powstałych interferencji (nachodzenia na siebie i znoszenia się fal dźwiękowych w wyniku źle ustawionego systemu elektroakustycznego);

- przetwarzania dźwięków zewnętrznych, które docierają do mikrofonów i są reprodukowane przez system elektroakustyczny;

- zbyt głośnego przetwarzania dźwięków mowy i śpiewu w bliskiej odległości od głośników lub zbyt cichego przetwarzania dźwięków w większej odległości od głośników (brak wyrównania natężenia dźwięku w całym budynku);

sakralnych, „Czasopismo Techniczne” 2-A/1 (2011), s. 116; L. BOuYER, Architektura i liturgia, Kraków 2009, s. 30-90; K. GAMBER, Zwróćmy się ku Panu! Zagadnienia dotyczace budownictwa kościelnego i modlitwy zwróconej na wschód, (tłum. G. Kucharczyk), Poznań 1998, s. 22-80.

8 Z. Engel, K. Kosala, Globalny wskaźnik oceny jakości akustycznej obiektów sakralnych, LI Otwarte Seminarium z Akustyki - OSA (Gdańsk, Sobieszewo, 6-10.09.2004 r.), Gdańsk 2004, s. 309-312.

${ }^{9}$ CH. ZIELIŃski, Sztuka sakralna. Co należy wiedzieć o budowie, urządzeniu, wyposażeniu, ozdobie i konserwacji Domu Bożego. Podręcznik opracowany na podstawie przepisów kościelnych, Poznań 1960, s. 49-79, 85-165.

10 A. Kulowski, D. WróBlewsKa, Czynniki akustyki, s. 30-33. 
- powstania punktów w kościele, gdzie słychać dobrze oraz gdzie słychać źle (w wyniku zbyt dużej lub zbyt małej ilości kolumn głośnikowych, które nie są prawidłowo skalibrowane względem pomieszczenia oraz względem siebie);

- zmiany atmosfery - tła akustycznego kościoła, które może być następstwem powstających hałasów, szumów i szmerów wynikłych z zastosowania nagłośnienia i mikrofonów, destrukcyjnie wpływając na wyciszenie się w modlitwie, skupienie się i przeżywanie Eucharystii przez wiernych.

Coraz częściej można spotkać się z błędnym przekonaniem, że wszelkie błędy architektoniczne wpływające na akustykę sal i pomieszczeń można poprawić przy pomocy odpowiedniego sprzętu elektroakustycznego ${ }^{11}$. Sprzęt bardzo wysokiej klasy wraz z modelowaniem matematycznym rozchodzenia się fal jest bardzo drogi. Innym problemem, jeszcze bardziej istotnym i zarazem bardziej złożonym, jest podstawowy błąd w faktycznym projekcie architektonicznym. Kościół zaprojektowany w sposób niewłaściwy nigdy nie będzie spełniał swojej funkcji ${ }^{12}$, pomimo zastosowania cyfrowych systemów elektroakustycznych. Właściwe i nieodzowne dla człowieka jest ogólne poczucie naturalności, m.in. brzmienia słowa lub śpiewu zgodne z prawami natury, ponieważ naturalna akustyka pomieszczenia, która ludziom jest najbliższa, silnie oddziałuje psychoakustycznie na wiernych, powodując wyciszenie i skupienie się na modlitwie oraz pozwala na pełne przeżycie Eucharystii ${ }^{13}$.

\section{Organy cyfrowe oraz instrumenty VSTi}

VST/VSTi (ang. Virtual Studio Technology/instruments) to specjalne oprogramowanie komputerowe, które zostało opracowane w 1996 r., wykorzystywane jest często przez producentów muzycznych do generowania i kreowania dźwięków przy pomocy komputera ${ }^{14}$. System VSTi przetwarza komunikaty cyfrowe, które mogą być wysyłane z cyfrowej klawiatury muzycznej (np. keyboardu lub syntezatora) na dźwięki różnych (wybranych) instrumentów, udostępniając je w formie

11 J. ZareK, Sound Amplification in Churches, London 1990, s. 5-19.

12 P. Költzsch, V. Bormann, Structure generation under subjectivity: Selected examples from acoustics, w: K. LuCAS, P. RoOSEN (red.), Emergence analysis and evolution of structures. Concepts and strategies across disciplines, Heidelberg 2010, s. 244.

13 M. Twarowski, Metoda projektowania kościoła, Warszawa 1985, s. 272. s. 34-35.

14 A. Rosiński, Wykorzystanie komputera w realizacji nagrań muzycznych, Bydgoszcz 2013, 
dźwięku audio w głośnikach lub specjalnie podłączonym nagłośnieniem do komputera $^{15}$. Oprogramowanie pozwala na kreowanie barw dźwiękowych, które nie istnieją w naturalnym środowisku człowieka, lub na złudne imitowanie dźwięków instrumentów tradycyjnych, jak np. organów kościelnych z włączonymi różnymi rejestrami. Aktualnie na rynku jest wiele instrumentów wirtualnych, które wiernie odwzorowują specyfikę i klasę barwy dźwięku danych instrumentów poprzez krótkie, zapętlone nagrania instrumentów tradycyjnych nazywane próbkami, dzięki czemu trudne jest odróżnienie instrumentu wirtualnego od jego tradycyjnego odpowiednika ${ }^{16}$, jednakże takie rozwiązania zastosowane w domu modlitwy mogą mieć poważne wady.

W przypadku organów kościelnych wielkość instrumentu i rozstawienie piszczałek powodują bardzo interesujący efekt propagacji (rozchodzenia się fal dźwiękowych) w pomieszczeniu. Organy oraz ich konstrukcja dobierana jest do pomieszczenia, w którym mają się znajdować, wypełniając pomieszczenie, w którym stoją, zarazem nośnym i delikatnym dźwiękiem ${ }^{17} \mathrm{~W}$ taki sposób, aby umożliwić w największym dostojeństwie korelację z Mszą, która pozwala na skupienie się i refleksję wiernych oraz na śpiewne wykonywanie pieśni ${ }^{18}$. Instrumenty wirtualne (komputerowe) czy cyfrowe (keyboardy, cyfrowe organy) nie są w stanie wygenerować właściwego pola akustycznego w porównaniu do instrumentu tradycyjnego, gdzie drżą całe grupy piszczałek (słupy wibrującego powietrza) w porównaniu nawet do najlepszego systemu elektroakustycznego podłączonego do instrumentu cyfrowego. Właściwe pole akustyczne generowane przez instrument tradycyjny powoduje, że dźwięk bez dużego natężenia jest nośny, a więc słyszalny, odbierany i interpretowany należycie przez osoby znajdujące się blisko tradycyjnych organów, jak i daleko od nich, powodując spójne brzmienie całego kościoła ${ }^{19}$.

Kolejny aspekt wskazuje na inne możliwości wykonawcze - sposób wydobycia dźwięku z elektronicznych instrumentów klawiszowych w porównaniu do instrumentów tradycyjnych. Wykształcony organista jest wysokiej klasy muzykiem wykonującym muzykę liturgiczną na instrumencie tradycyjnym ${ }^{20}$, natomiast s. 12.

15 M. Coluns, Pro Tools for Music Production. Recording, editing and mixing, Oxford 2004,

${ }^{16}$ S. McGuire, R. Pritts, Audio Sampling. A practical guide, Amsterdam - Boston 2008, s. 1-11.

17 B. Szudrowicz, Normowanie wartości, s. 11-12.

18 M. Twarowski, Metoda projektowania, s. 272.

19 A. Rosiński, Wybór systemu nagłośnienia pomieszczeń sakralnych, „Colloquia Theologica Ottoniana" 2 (2013), Szczecin 2013, s. 172.

${ }^{20} \mathrm{~W}$. ZALEWSKI, Polska twórczość organowa zainspirowana pieśnia kościelna w liturgii Kościoła rzymskokatolickiego, cz. I, „Pro Musica Sacra” 12 (2014), s. 174. 
umiejętność programowania instrumentów cyfrowych, która jest wymagana, jako znawstwo w zakresie ich obsługi, jest procesem wkraczającym na grunt wyłącznie techniczny ${ }^{21}$, a nie artystyczny. Wysoka jakość muzyki w kościele nie może być oparta na umiejętności programowania cyfrowych instrumentów oraz emulacji brzmienia, zastępując instrument tradycyjny - elektronicznym, tylko na umiejętności gry liturgicznej, która podkreśla walory twórcze (improwizacja organowa) $\mathrm{i}$ artystyczne (wspólne wykonanie dzieła $\mathrm{z}$ wiernymi) ${ }^{22}$. Edukacja w zakresie możliwości technicznych instrumentów cyfrowych jest bezcelowa, ponieważ każdy z instrumentów cyfrowych brzmi odmiennie (barwą często niezgodną z brzmieniem danego pomieszczenia) oraz dodatkowo każdy z instrumentów obsługiwany jest w odmienny sposób.

Ostatnim aspektem jest budowa instrumentu cyfrowego, który nie pozwala na zastosowanie różnych mechanizmów klawiatury, jakie stosuje się w organach kościelnych - tradycyjnych, oraz możliwości odczucia stopnia twardości klawiatury, która może być zmienna w organach tradycyjnych w zależności od ilości włączonych piszczałek - tworzących miksturę danego brzmienia (zależnie od rodzaju traktury instrumentu tradycyjnego). Gra na instrumencie cyfrowym stwarza zupełnie odmienne warunki techniczne gry dla organisty grającego na tradycyjnym instrumencie, które zarazem mogą być trudne do opanowania oraz mogą być niepotrzebne w kościele.

\section{Oświetlenie LED}

Wielokolorowe oświetlenie diodowe LED coraz częściej jest stosowane w kościołach. Oświetlenie diodowe RGB zbudowane jest z trzykolorowych diod, które zmieniając swoją intensywność świecenia oraz barwę, powodują powstawanie wielu różnych kolorów poprzez mieszanie się barw ich światła ${ }^{23}$. RGB jest skrótem do określania kolorów z zakresu światła widzialnego (Red - czerwony, Green zielony, Blue - niebieski) ${ }^{24}$. Oświetlenie LED-owe może być wykorzystane do

${ }^{21}$ A. Pejrolo, R. DeRosa, Acoustic and MIDI orchestration for the contemporary composer. A practical guide to writing and sequencing for the studio orchestra, Oxford 2009, s. 1-26.

22 J. SurzyŃSKi (red.), Znaczenie organisty w kościele, „Muzyka Kościelna” 7 (1893), s. 50-53.

23 J. Gondek, S. Kordowiak, K. RatyŃSKI, Cyfrowe programowalne sterowniki hybrydowe dla diod LED, „Electrical Engineering” 79 (2014), s. 253-255.

${ }^{24}$ S. ZALEWSKI, Właściwości świetlne opraw drogowych LED (ocena przydatności diod LED w oświetleniu drogowym), „Oświetlenie LED”, 1 (2011), s. 23, 25; I. Moreno, U. ConTreras, Color distribution from multicolor LED arrays, „Optics Express” 15 (2007), nr 6, s. 3611. 
podkreślenia aspektów wizualnych, np. do uzyskania odpowiedniej atmosfery wewnątrz kościoła. Wzmiankowane oświetlenie właściwie ustawione wraz z doborem odpowiedniego koloru, jako swoistego rodzaju oświetlacz, może powodować powstanie pewnego rodzaju ,intymności” w świątyni, ponieważ światłocień może stymulować wyobraźnię wiernych, wpływając na atmosferę ${ }^{25}$ odczuwaną w świątyni. Prawidłowe wykorzystanie oświetlenia LED opiera się na wybraniu odpowiednich lamp - oświetlaczy, bez wbudowanego wentylatora, zapewniając ciszę podczas nabożeństw i modlitwy, oraz na doborze lamp o dość szerokiej bądź wąskiej wiązce światła (w zależności od tego, jaki element pomieszczenia chcemy oświetlić), wybierając mało intensywną jasność światła wraz z tzw. ciepłą kolorystyką ${ }^{26}$ (tzw. ciepły biały).

Największym problemem zastosowania lamp LED-owych we wnętrzach kościelnych jest nierzadko ich zły dobór do odpowiedniej wielkości pomieszczenia. Nagminnie stosowane są lampy o silnej i bardzo wąskiej wiązce światła, które nie doświetlają danej przestrzeni, lecz ją w pełni koloryzują, co w wielu przypadkach razi wiernych w oczy. Wykorzystanie silnej mocy źródła światła prowadzi do niezadowalających efektów wizualnych. Jeżeli w danych wnętrzach kościelnych są stosowane lampy LED-owe, to powinny być zastosowane urządzenia o szerokich kątach świecenia (szeroka wiązka) oraz o mniejszej mocy światła, dzięki czemu takie kolory, jak czerwień, purpura, fiolet, dodadzą danemu wnętrza uroku i nie pozbawią kościoła sacrum. Kolory tzw. zimne (np. niebieski) lub zbyt jasne, np. biały (zimny), intensywny żółty, powinny być włączane w kościele z umiarem. Szczególną uwagę należy zwrócić podczas stosowania kolorów pulsujących, bądź zmiennych (nawet zmieniających się i pulsujących bardzo wolno), ponieważ takie efekty świetlne mogą odwracać uwagę od głębokiej i świadomej modlitwy, czyli od właściwego i precyzyjnego zrozumienia przekazu słowa głoszonego przez kapłana podczas mszy.

\section{Cyfrowe wyświetlacze tekstu}

Tradycyjna tablica wraz z projektorem bywa często nieodzownym elementem wyposażenia każdego kościoła. Wyświetlany tekst śpiewany przez organistę ma za zadanie zachęcić do wspólnego uczestniczenia w Eucharystii poprzez śpiew

${ }^{25}$ S. ABramik, W. WeADziński, Nowoczesne systemy oświetleniowe z diodowymi źródłami światła, „Wiadomości Elektrotechniczne” 75 (2007), nr 10, s. 42-45.

${ }^{26}$ K. StrzaŁKa-GoluszKa, Diody LED w oświetleniu zewnętrznym i iluminacji, „Energetyka” 4 (2017), s. 281-287. 
wszystkich zgromadzonych w kościele. Nie każdy z wiernych musi pamiętać teksty wszystkich pieśni, psalmów itp., stąd tablica z projektorem ułatwia pracę organisty z wiernymi, którzy w odpowiednim momencie intonując, wypowiadają właściwy tekst pieśni, psalmów itp.

Zastosowanie technologii cyfrowych w postaci elektronicznych wyświetlaczy LED o jednym kolorze światła jest bardzo dobrym i przemyślanym rozwiązaniem, ponieważ małe i blisko ułożone siebie diody LED powodują wrażenie bardzo wysokiego kontrastu wyświetlanych treści. Zastosowanie diod o pomarańczowej barwie oraz o bardzo wysokiej jasności powoduje, że tekst zaprezentowany na wyświetlaczu jest bardzo dobrze widoczny w słońcu oraz z dużych odległości nawet przez osoby słabiej widzące.

Wyświetlacze $\mathrm{w}$ formie wielkoformatowych telewizorów/monitorów nie są najlepiej przystosowane do zastosowania ich w kościele. Zastosowanie biało-niebieskiego podświetlenia w ekranach tego typu oraz wyświetlanie tekstu podczas mszy zwłaszcza wieczornych powoduje, że światło żółte pochodzące z żarówek (lub żółte światło słoneczne w dzień) oraz biało-niebieskie światło emitowane z wielkiego monitora nie wygląda właściwie. Kolor podświetlenia wydobywający się z ekranu monitora oświetla kilka pierwszych rzędów ławek po jednej stronie, co powoduje nierówne oświetlenie kościoła poprzez emisję światła białego koloru „zimnego”, który w świątyni nie powinien występować. Monitor wielkoformatowy może razić w oczy przy dużej różnicy natężeń światła wewnątrz świątyni, męcząc oczy wiernych zasiadających w kilku pierwszych rzędach ławek od strony monitora. Wykorzystanie wspomnianego wyświetlacza lub monitora wielkoformatowego ma sens pod warunkiem jego właściwej kalibracji względem kolorystyki i jasności pomieszczenia. Działanie w tym przypadku powinno się opierać na kalibracji podwójnej, dotyczącej dnia i zmierzchu, gdzie kolorystyka, kontrast oraz natężenie światła powinno być zmienne - dobrane do zmieniających się warunków zewnętrznych.

\section{Zakończenie}

Naturalna akustyka pomieszczeń sakralnych jest niezwykle ważna, ponieważ dzięki niej wierni mogą jednoczyć i wyciszać się we wspólnej modlitwie, co jest podstawą osiągania właściwego celu, dla którego buduje się domy modlitwy. Aktualnie żadne systemy elektroakustyczne nie mogą w pełni zapewnić stuprocentowej - właściwej akustyki w kościele, czyli nie są stanie w sposób idealny poprawić i zniwelować problemy oraz niedbałości w zakresie projektowania wnętrz sakral- 
nych, ponieważ naturalne rozchodzenie się dźwięku bez zastosowania cyfrowego modelowania akustyki jest człowiekowi bardzo bliskie.

Zastosowanie zamienników lub pewnego rodzaju substytutów organów kościelnych w postaci organów cyfrowych i wirtualnych może nie spełniać kryteriów brzmieniowych stawianych instrumentom akompaniującym do mszy, ponieważ wzmiankowane instrumenty cyfrowe nie są w stanie wygenerować takiego pola akustycznego jak instrumenty tradycyjne. Programowanie instrumentów cyfrowych nie spełnia ważnych kryteriów artystycznych, które są obecne w kościele od wieków, lecz spełnia wyłącznie kryteria techniczne w zakresie umiejętności obsługi cyfrowych urządzeń. Instrumenty wirtualne i elektroniczne mogą stwarzać odmienne warunki gry (poprzez zastosowanie innych elementów budowy w porównaniu do instrumentów tradycyjnych), których mogą nie znać i do których nie są przyzwyczajeni organiści grający na instrumentach tradycyjnych, stąd zastosowanie instrumentów cyfrowych podczas mszy w domu modlitwy powinno zostać ograniczone do minimum, o ile kościół posiada tradycyjne organy.

Zastosowanie oświetlenia typu LED oraz cyfrowych wyświetlaczy tekstu w kościołach, jest uprawnione pod warunkiem korzystnego dobrania odpowiedniej kolorystyki światła i jego jasności do pomieszczenia, w którym mają się znajdować dane urządzenia. Oświetlenie LED powinno opierać się na kolorach delikatnych, doświetlających dane elementy pomieszczenia, tworząc swoisty „nastrój” kościoła, który polecany jest do modlitwy. Ważnym elementem jest również temperatura barwowa urządzeń wyświetlających, które powinny zbliżać się do światła biało-żółtego, podobnego do oświetlenia, które posiadamy w domach, a nie do „zimnego" światła biało-niebieskiego, które jest niekorzystne dla oczu.

To nie technologia cyfrowa i jej rozwój wpływają na zastosowanie technologii w materialnej przestrzeni budynków sakralnych, lecz człowiek poinformowany o wadach i zaletach danych rozwiązań technologicznych - wykorzystania urządzeń cyfrowych i skomputeryzowanych w kościele, powinien wykorzystywać ową technologię z rozwagą oraz umiarem. Technologia cyfrowa nadal będzie ingerować w życie człowieka, będzie podlegać dalszym przekształceniom i rozwojowi bez względu na to, czy ludzie zaakceptują nowoczesność i daleko idące zmiany. Świadome decyzje przy wznoszeniu budowli sakralnych bądź remontach wnętrz sakralnych wyposażanych w nową, dostępną technologię są właściwym posunięciem, jeżeli wszystkie elementy technicznej „nowatorskości” łączą się we wspólny, spoisty element, nie przeszkadzając sobie, lecz wzajemnie się uzupełniając wraz $\mathrm{z}$ historią i tradycją. 


\title{
Streszczenie
}

Obecność urządzeń techniki cyfrowej na każdym etapie życia ludzkiego nie zostaje bez wpływu na kształt kultury współczesnej, która w dużym stopniu może oddziaływać na funkcjonowanie kościołów w Polsce. Autor niniejszej pracy, poinformowany o wadach i zaletach cyfryzacji, skupił się jedynie na wybranych elementach zastosowania urządzeń techniki cyfrowej w kościele, takich jak: cyfrowe modelowanie akustyki obiektów sakralnych, w tym wykorzystanie mikrofonów i głośników do nagłośnienia kościoła, zastosowanie organów elektronicznych, cyfrowe oświetlenie wielokolorowe typu LED, wyświetlacz tekstów pieśni kościelnych dla wiernych.

Słowa kluczowe: Kościół, komputer, nowe media, technologie cyfrowe, elektronika użytkowa.

\section{Usage of digital technology in sacral building space}

\begin{abstract}
The presence of digital devices at every aspect of life surely affects the contemporary culture, what may have a big impact on functioning of churches in Poland. The article's author, aware of the disadvantages and advantages of digitization, focuses exactly on select elements of digital technology usage in churches, such as digital modelling of acoustics of sacral buildings, including the use of microphones and loudspeakers for church's sound system, digital multicolour LED lighting, screens displaying texts of the religious songs for the church attendees.
\end{abstract}

Keywords: Church, computer, new media, digital technology, consumer electronics.

\section{Bibliografia:}

Abramik S., WŁadziński W., Nowoczesne systemy oświetleniowe z diodowymi źródtami światła, „Wiadomości Elektrotechniczne”, 75 (2007), nr 10.

BOUYer L., Architektura i liturgia, (tłum. P. Włodyga), Kraków 2009.

Collins M., Pro Tools for Music Production. Recording, editing and mixing, Oxford 2004. 
Engel Z., KosaŁa K., Globalny wskaźnik oceny jakości akustycznej obiektów sakralnych (LI Otwarte Seminarium z Akustyki - OSA, Gdańsk, Sobieszewo, 6-10.09.2004 r.), Gdańsk 2004, s. 309-312.

Flew T., Media globalne, (thum. M. Lorek), Kraków 2010.

GAJEK E., Edukacja językowa w społeczeństwie informacyjnym, Warszawa 2008.

GAMBER K., Zwróćmy się ku Panu! Zagadnienia dotyczace budownictwa kościelnego i modlitwy zwróconej na wschód, (tłum. G. Kucharczyk), Poznań 1998.

GondeK J., Kordowiak S., RatYŃski K., Cyfrowe programowalne sterowniki hybrydowe dla diod LED, ,Electrical Engineering” 79 (2014).

KAMIŃSKi T., KosaŁA K., Akustyka wielofunkcyjna wnętrz sakralnych, „Czasopismo Techniczne" 2-A/1 (2011).

Költzsch P., Bormann V., Structure generation under subjectivity: Selected examples from acoustics, w: K. LUCAS, P. RoOSEN (red.), Emergence analysis and evolution of structures. Concepts and strategies across disciplines, Heidelberg 2010.

KULOWSKi A., WróBlewsKa D., Czynniki akustyki w architektonicznym projektowaniu kościołów, Gdańsk 2007.

McGuire S., Pritts R., Audio Sampling. A practical guide, Amsterdam - Boston 2008.

Moreno I., Contreras U., Color distribution from multicolor LED arrays, „Optics Express", 15 (2007), nr 6.

PaWelski L., Komputer jako narzędzie pracy dydaktycznej $i$ administracyjnej w szkole, w: Z. PŁoszyński, A. PATRYN (red.), Komputer - wspótczesne narzędzie pracy nauczyciela, Słupsk 2003.

Pejrolo A., DeRosa R., Acoustic and MIDI orchestration for the contemporary composer. A practical guide to writing and sequencing for the studio orchestra, Oxford 2009.

RosińsKi A., Cyberkultura i twórczość digitalna jako moda w społeczeństwie multimedialnym, „Muzyka. Historia. Teoria. Edukacja” 6 (2016).

Rosiński A., Wybór systemu nagłośnienia pomieszczeń sakralnych, „Colloquia Theologica Ottoniana" 2 (2013).

RosińsKi A., Wykorzystanie komputera w realizacji nagrań muzycznych, Bydgoszcz 2013.

SIENKIEwIcz P., Społeczeństwo informacyjne jako społeczeństwo ryzyka, w: L.H. HABER, M. NiezGoda (red.), Społeczeństwo informacyjne. Aspekty funkcjonalne i dysfunkcyjne, Kraków 2006.

StrzalKa-Goluszka K., Diody LED w oświetleniu zewnętrznym i iluminacji, „Energetyka” 4 (2017). 
SuRzYŃSKi J. (red.), Znaczenie organisty w kościele, „Muzyka Kościelna” 7 (1893).

Szudrowicz B., Normowanie wartości czasu pogłosu w pomieszczeniach - założenia do normy PN, ,Materiały Budowlane” 8 (2009).

Twarowski M., Metoda projektowania kościoła, Warszawa 1985.

ZALEWSKI S., Właściwości świetlne opraw drogowych LED (ocena przydatności diod LED w oświetleniu drogowym), „Oświetlenie LED” 1 (2011).

ZALEWSKI W., Polska twórczość organowa zainspirowana pieśnia kościelna w liturgii Kościoła rzymskokatolickiego, cz. I, „Pro Musica Sacra” 12 (2014).

ZAReK J., Sound Amplification in Churches, London 1990.

ZIELIŃski CH., Sztuka sakralna. Co należy wiedzieć o budowie, urządzeniu, wyposażeniu, ozdobie i konserwacji Domu Bożego. Podręcznik opracowany na podstawie przepisów kościelnych, Poznań 1960.

ADAm Rosiński, doktor sztuki w dziedzinie sztuk muzycznych w dyscyplinie kompozycja i teoria muzyki. Adiunkt na Wydziale Sztuki w Instytucie Muzyki Uniwersytetu Warmińsko-Mazurskiego w Olsztynie.E-mail: adammuzyk@gmail.com. 